\title{
Global Longitudinal Strain and Strain Rate in Type Two Diabetes Patients with Chronic Heart Failure: Relevance to Osteoprotegerin
}

\author{
Peter Kruzliak ${ }^{1}$, Alexander Berezin ${ }^{2}$, Alexander Kremzer ${ }^{3}$, Tatyana Samura ${ }^{3}$, Roman Benacka ${ }^{4}$, \\ loana Mozos ${ }^{5}$, Emmanuel Egom ${ }^{6}$, Luis Rodrigo ${ }^{7}$ \\ ${ }^{1}$ Laboratory of Structural Biology and Proteomics, University of Veterinary and Pharmaceutical Sciences, Brno, Czech Republic \\ ${ }^{2}$ Department of Internal Medicine, State Medical University, Zaporozhye, Ukraine \\ ${ }^{3}$ Department of Clinical Pharmacology, State Medical University, Zaporozhye, Ukraine \\ ${ }^{4}$ Benimed Ltd \\ ${ }^{5}$ Department of Functional Sciences, Victor Babes University of Medicine and Pharmacy, Timișoara, Romania \\ ${ }^{6}$ Department of Clinical Medicine, Education Division, Trinity College, University of Dublin, Dublin, Ireland \\ ${ }^{7}$ Central University Hospital of Asturia, University of Oviedo, Oviedo, Spain
}

Correspondence: P. Kruzliak, University of Veterinary and Pharmaceutical Sciences, Laboratory of Structural Biology and Proteomics. Palackeho tr 1946/1 Brno, 612 42, Czech Republic E-mail: peter.kruzliak@savba.sk Tel.: +420543181111; mob: $+420543181111$

Received: 26 May 2016 Accepted: 31 May 2016 Published Online:25 July 2016 Published: 30 Sep 2016

Key words: chronic heart failure, global longitudinal strain and strain rate, osteoprotegerin, brain natriuretic peptide

Citation: Kruzliak P, Kremzer A, Samura T, Benacka R, Mozos I, Edom E, Rodrigo L. Global longitudinal strain and strain rate in type two diabetes patients with chronic heart failure: relevance to osteoprotegerin.

Folia Medica 2016;58(3);164-173, doi: 10.1515/folmed-2016-0021
Background: Biomechanical stress and inflammatory biomarkers relate to global contractility dysfunction; however, adding these biomarkers into a risk model constructed on clinical data does not improve its prediction value in chronic heart failure (CHF).

Aim: The aim of this study was to evaluate whether biomarkers predict declining of left ventricular global contractility function in diabetic patients with ischemiainduced CHF.

Patients and Methods: The study retrospectively evolved 54 diabetic patients who had systolic or diastolic ischemia-induced $\mathrm{CHF}$ that was defined as left-ventricular ejection fraction (LVEF) $\leq 45 \%$ or $46-55 \%$ respectively assessed by quantitative echocardiography and other conventional criteria according to current clinical guidelines. Two-dimensional transthoracic echocardiography and tissue Doppler imaging were performed according to a conventional method. Radial, longitudinal, and circumferential strain and strain rate values were obtained by speckle-tracking Imaging analysis of both LV short axis and long axis views. Serum adiponectin, NT-pro brain natriuretic peptide (BNP), osteoprotegerin, and hs- Creactive protein (CRP) were determined at baseline by ELISA.

Results: We found lower global longitudinal strain and strain rate in diabetic patients with LVEF $<45 \%$ than these in diabetic patients that did not have LVEF $(\mathrm{P}=0.001$ for all cases). Multivariate logistic regression analysis showed that NTproBNP ( $r=0.432 ; P=0.001$ and $r=0.402 ; P=0.001$, respectively), osteoprotegerin $(r=0.422 ; P=0.001$ and $r=0.401 ; P=0.001$, respectively), hs-CRP $(r=0.408 ; P=0.001$ and $r=0.404 ; P=0.001$, respectively) were independently inversely associated with global longitudinal strain and strain rate in CHF patients.

Conclusion: We suggest that osteoprotegerin may be useful in improving the NT-proBNP based model as predictor of decreased global contractility function in diabetic patients with $\mathrm{CHF}$.

\section{INTRODUCTION}

Chronic heart failure (CHF) remains a leading cause of cardiovascular morbidity and mortality worldwide. ${ }^{1,2}$ In fact, metabolic comorbidities such as diabetes mellitus, obesity, and insulin resistance are reported as predictors of CHF in generally population alongside with these discussed as aggravating factors for worsening of CHF. 3,4 Dysmetabolic conditions may contribute to decreasing the global cardiac deformations frequently affecting both right and left ventricles and associated with worsening of longitudinal, radial, and circumstance strain and strain rate. ${ }^{5,6}$ Although global longitudinal strain is well validated as reproducible technique for the measurement of ventricular longitudinal deformation with predictive value regarding a composite of cardiac death, malignant arrhythmia, hospitalization due to CHF, urgent valve surgery 
or heart transplantation, as well as acute coronary ischemic events ${ }^{7}$, the innate mechanisms that directly mediate cardiac mechanical disturbance are still uncertain ${ }^{8}$. Moreover, whether the predictive value of left ventricular global longitudinal strain is similar for patients with declined and preserved left ventricular (LV) ejection fraction (EF) is under recognized. ${ }^{9}$ In this context, discover and validate biomarkers for improving prediction value of global longitudinal strain is considered optimistically. ${ }^{10}$ Currently emerging inflammatory (high-sensitive C-reactive protein [hs-CRP], osteoprotegerin) and biomechanical stress ( $\mathrm{N}$-terminal brain natriuretic peptide [NT-proBNP]) biomarkers are independently associated with all-cause mortality in patients with acute, acutely decompensated and chronic heart failure. ${ }^{11-14}$ However, adding this biomarker into a risk model constructed on clinical data does not improve its prediction value, especially in diabetic population, while they relate to global contractility dysfunction. ${ }^{15}$ The aim of this study was to evaluate whether biomarkers predict declining of left ventricular global contractility function in diabetic patients with ischemia-induced CHF.

\section{PATIENTS AND METHODs}

\section{PATIENTS}

The study retrospectively evolved $54 \mathrm{~T} 2 \mathrm{DM}$ patients who had systolic or diastolic ischemia-induced CHF defined as LVEF $\leq 45 \%$ or $46-55 \%$, respectively, assessed by quantitative echocardiography and other conventional criteria according to current clinical guidelines. ${ }^{16}$ Criteria of ischemic-induced CHF were discharge from the hospital after Q-wave myocardial infarction (MI) more than 3 months prior to study entry or underwent coronary angiography / revascularization procedures between February 2010 and July 2014. All the patients gave their written informed consent for participation in the study. The following are the exclusion criteria: severe kidney and liver diseases, malignancy, brain injury within 3 months before enrollment, ischemic stroke, intracranial hemorrhage, pulmonary edema, valvular heart disease, thyrotoxicosis, acute infections, trauma, inflammations within a previous month, pregnancy, implanted pacemaker.

T2DM was diagnosed with revised criteria provided by American Diabetes Association. ${ }^{17}$ When one or more of the following components were found (glycated hemoglobin $[\mathrm{HbA} 1 \mathrm{c}] \geq 6.5 \%$; fasting plasma glucose $\geq 7 \mathrm{mmol} / \mathrm{L}$; 2 -h plasma glucose $\geq 11.1 \mathrm{mmol} / \mathrm{L}$ during an oral glucose tolerance test; a random plasma glucose $\geq 11.1 \mathrm{mmol} / \mathrm{L}$; exposure of insulin or oral antidiabetic drugs; a previous diagnosis of T2DM) T2DM was diagnosed.

Current smoking was defined as consumption of one cigarette daily for three months. Anthropometric measurements were made using standard procedures. Patients with T2DM were treated with life-style modification, diet and orally taken antidiabetic drugs except sulfonylurea derivates and glitazones. Metformin was given in individually optimized daily doses to be achieving full or partly full control for T2DM. Therefore, insulin was not used in enrolled patients.

\section{TRANSTHORACIS ECHOCARDIOGRAPHY}

Two-dimensional transthoracic echocardiography, Tissue Doppler Imaging, and Speckle Tracking TwoDimensional Echo-Cardiography (2D-STE) were performed according to a conventional method on My Lab 50 scanner (ESAOTE, Italy) equipped with an phased probe of 2.5-5.0 MHz. Left ventricular (LV) end-diastolic (LVEDV) and LV end-systolic volumes (LVESV), and LVEF were measured by modified Simpson's method. ${ }^{18}$

Radial, longitudinal, and circumferential strain and strain rate values were obtained by SpeckleTracking Imaging analysis of both apical LV short axis and long axis views. ${ }^{19}$ The analysis was performed off-line using the original program with Two-Dimensional Strain Rate Imaging Software (SIEMENS, Germany) according to conventional method. ${ }^{20}$ Fig. 1 shows Two-Dimensional Strain Rate echocardiography to assess heart function.

All ECG recording were collected and reviewed by unblinded single operator. The average peak systolic $(\mathrm{Sm})$, early diastolic $(\mathrm{Em})$, and late diastolic (Am) myocardial velocities were measured. Early diastolic left ventricular filling (E) to the $\mathrm{Am}(\mathrm{E} / \mathrm{Am})$ ratio and to the $\mathrm{Em}(\mathrm{E} / \mathrm{Em})$ ratio were calculated. ${ }^{21}$

\section{Calculation of glomerular filtration Rate}

Glomerular filtration rate (GFR) was calculated with CKD-EPI formula before enrollment of the patients in the study. ${ }^{22}$

\section{Measurement of Circulating BiOMARKers}

To determine circulating biomarkers, blood samples were collected at baseline in the morning (at 7-8 a.m.) into cooled silicone test tubes wherein $2 \mathrm{~mL}$ of 5\% Trilon B solution were added. Then they were centrifuged upon permanent cooling at $6,000 \mathrm{rpm}$ for 3 minutes. Plasma was collected and refrigerated 

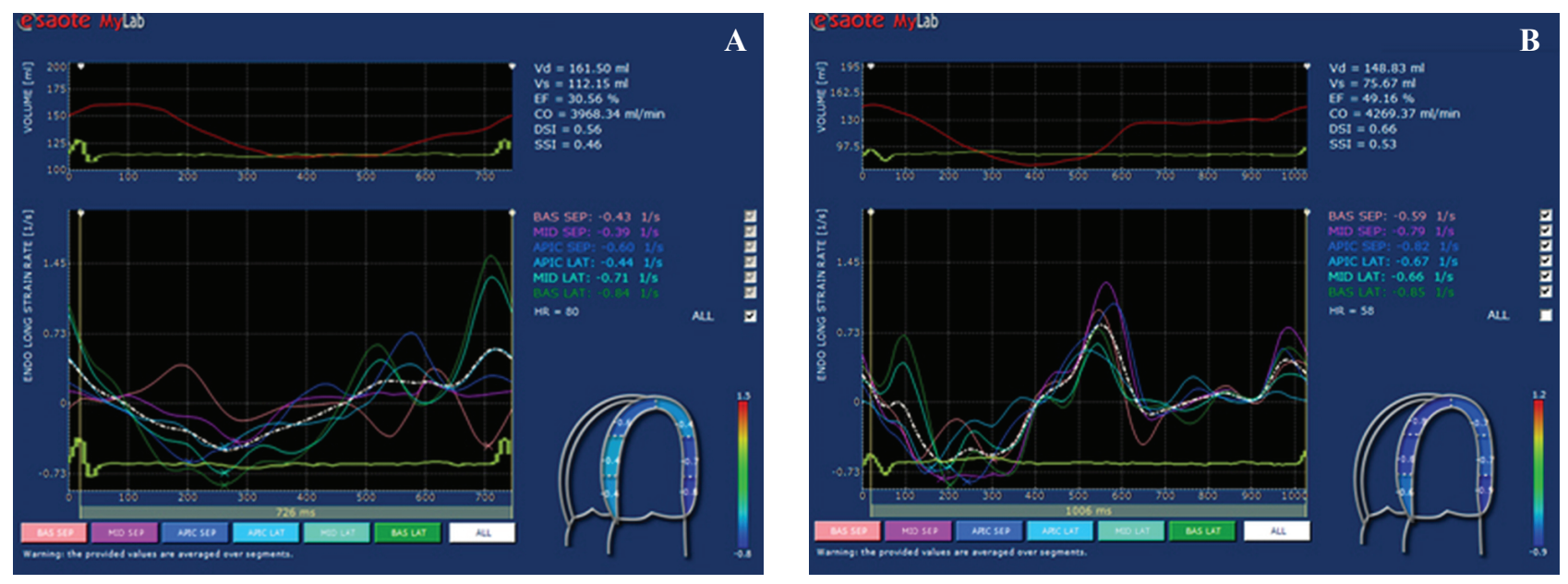

Figure 1. Two-Dimensional Strain Rate echocardiography. The results of speckle-tracking imaging analysis for CHF patients with $\mathrm{LVEF} \leq 45 \%$ (Fig. 1A) and $\mathrm{LVEF}=46-55 \%$ (Fig. 1B).

immediately to be stored at a temperature of $-70^{\circ} \mathrm{C}$. Serum adiponectin, NT-proBNP, osteoprotegerin were measured by high-sensitive enzyme-linked immunosorbent assays using commercial kits (R\&D Systems GmbH, Wiesbaden-Nordenstadt, Germany) according to the manufacturers' recommendations. The inter-assay coefficients of variation were as follows: adiponectin $=5 \%$, NT-proBNP $=6.8 \%$, osteoprotegerin $=8.2 \%$. High-sensitive C-reactive protein (hs-CRP) was measured by commercially available standard kit (R\&D Systems GmbH, Wiesbaden-Nordenstadt, Germany). The intra-assay and inter-assay coefficients of variation were $<5 \%$.

Fasting insulin level was measured by a doubleantibody sandwich immunoassay (Elecsys 1010 analyzer, F. Hoffmann-La Roche Diagnostics, Mannheim, Germany). The intra-assay and interassay coefficients of variation were $<5 \%$. The lower detection limit of insulin level was $1.39 \mathrm{pmol} / \mathrm{L}$.

Insulin resistance was assessed by the homeostasis model assessment for insulin resistance (HOMAIR $)^{23}$ using the following formula:

HOMA-IR $(\mathrm{mmol} / \mathrm{L} \times \mu \mathrm{U} / \mathrm{mL})=$ fasting glucose $(\mathrm{mmol} / \mathrm{L}) \times$ fasting insulin $(\mu \mathrm{U} / \mathrm{mL}) / 22.5$

Insulin resistance was defined when estimated HOMA-IR value was over $2.77 \mathrm{mmol} / \mathrm{L} \times \mu \mathrm{U} / \mathrm{mL}$.

Concentrations of total cholesterol (TC) and cholesterol of high-density lipoproteins (HDL-C) were measured by enzymatic method. Concentration of cholesterol of low-density lipoproteins (LDL-C) was calculated according to the Friedewald formula (1972)..$^{24}$

\section{STATISTICAL ANALYSIS}

Statistical analysis of the results obtained was performed in SPSS system for Windows, Version 22 (SPSS Inc, Chicago, IL, USA). Normal distribution of interval data was checked. The data were presented as mean (M) and standard deviation $( \pm \mathrm{SD})$ or $95 \%$ confidence interval $(\mathrm{CI})$; as well as median (Me) and 25\%-75\% interquartile range (IQR). To compare the main parameters of patient cohorts, two-tailed Student t-test or Mann Whitney U-test were used. To compare categorical variables between groups, $\mathrm{Chi}^{2}$ test $\left(\chi^{2}\right)$ and Fisher $\mathrm{F}$ exact test were used. Predictors of decreased global strain rate in patients were examined in univariable and multivariable regression analysis. Coefficient of variables in the model and their relevant $p$ values, odds ratios (OR) and their CI 95\% were calculated for all predictors. A two-tailed probability value of $<0.05$ was considered as significant.

\section{RESULTS}

\section{GeNERAL CHARACTERISTIC OF PARTICIPANTS}

General characteristic of patients participating in the study is presented in Table 1. The mean age for patients with T2DM was 48.50 years. Sixty three percent of the subjects were male. The median of body mass index (BMI) and waist circumference were referred $28.5 \mathrm{~kg} / \mathrm{m}^{2}$ and $89 \mathrm{~cm}$. Cardiovascular risk factors, i.e. hypertension, dyslipidemia, smoking, were found in $66.7 \%, 61.1 \%$, and $27.7 \%$ patients, respectively. The most subjects were experienced III $(61.1 \%)$ and IV (29.6\%) class NYHA of CHF. Circulating biomarkers of inflammatory activity (hs-CRP), biomechanical stress (NT-proBNP, osteoprotegerin), dysmetabolic changes (adiponectin) 


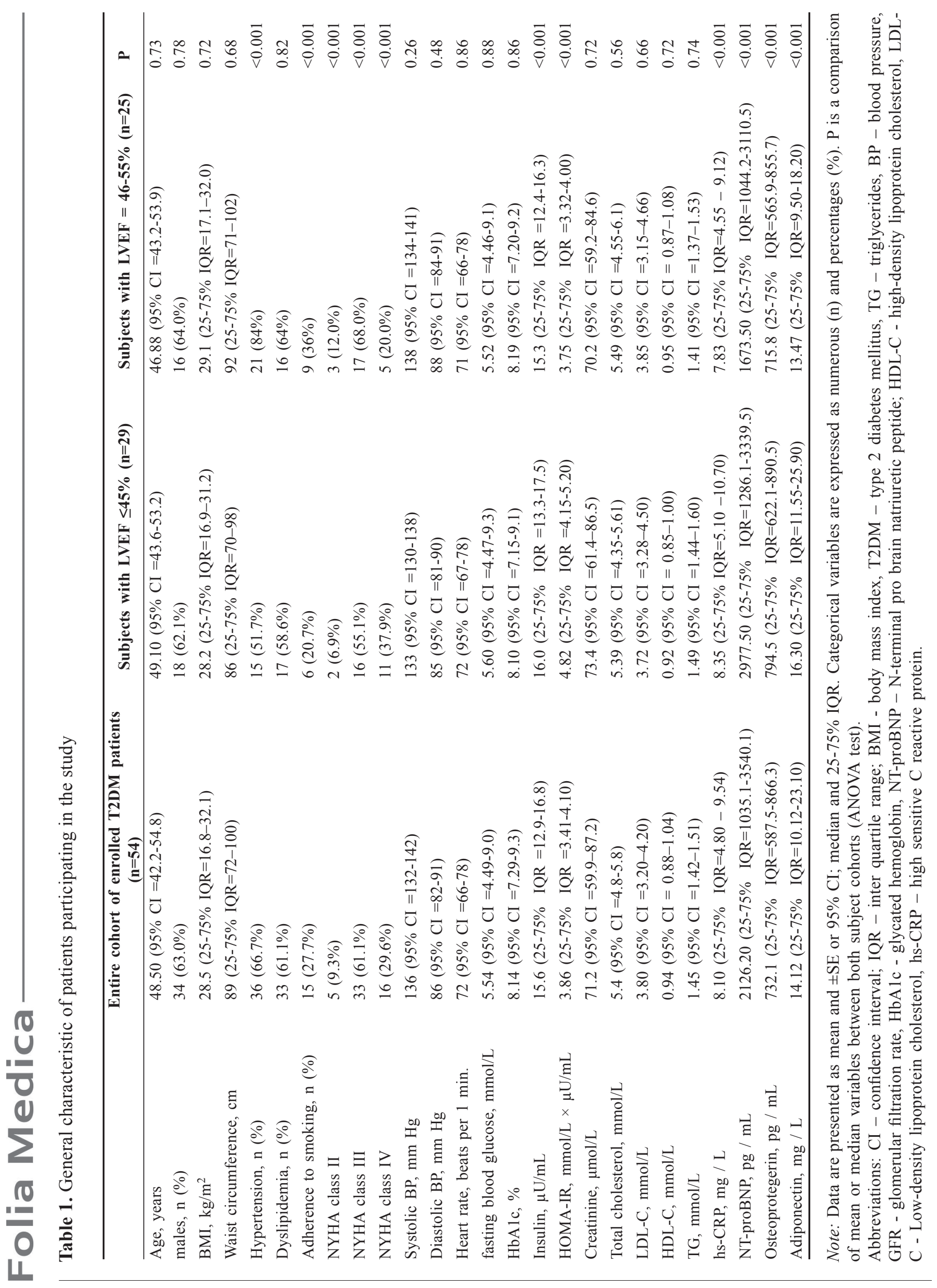




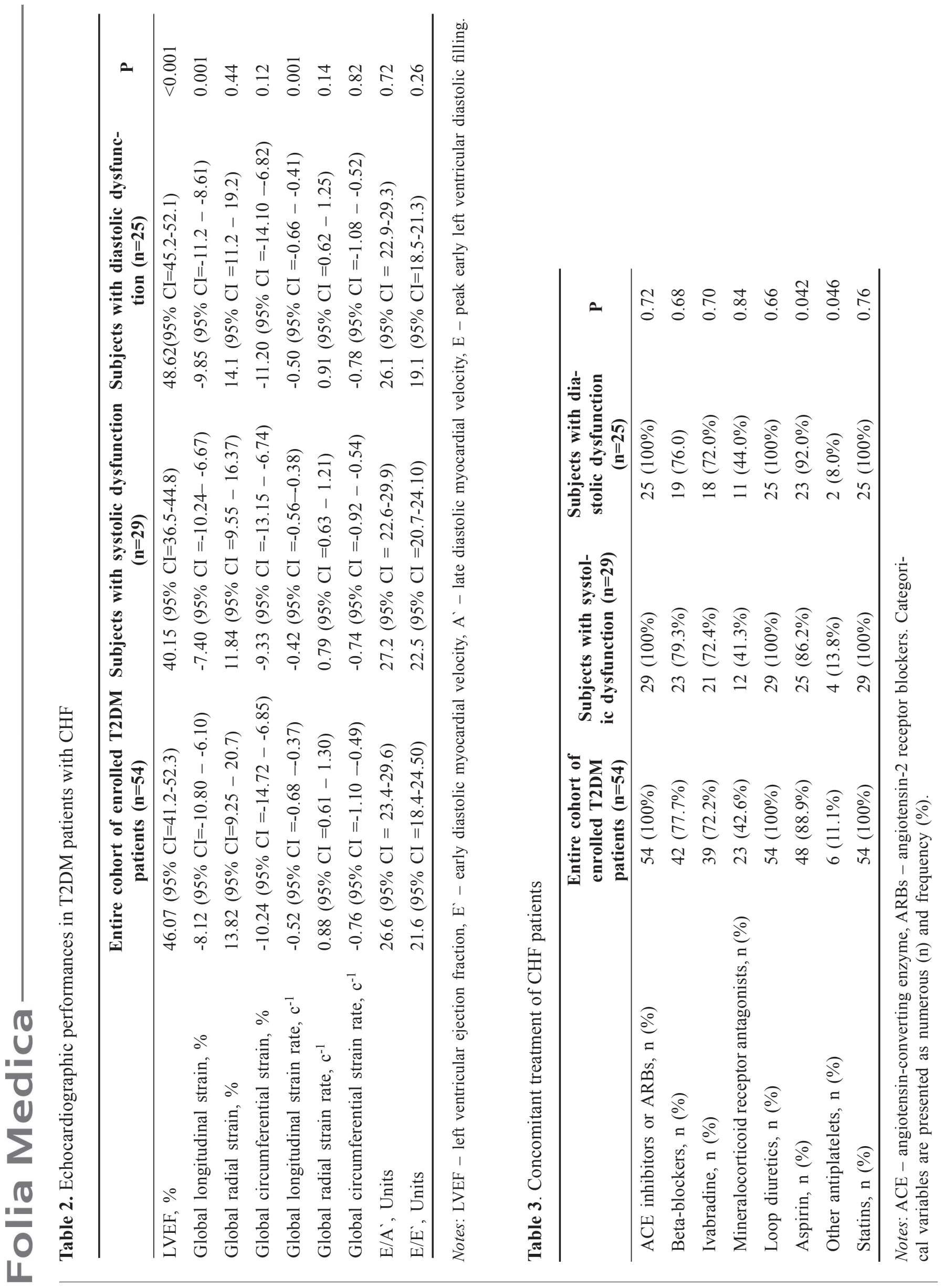


Table 4. Multivariate analysis for the variables of LV global longitudinal strain and global longitudinal strain rate in CHF patients

\begin{tabular}{lllll}
\hline & $\begin{array}{c}\text { Entire cohort of } \\
\text { enrolled T2DM } \\
\text { patients (n=54) }\end{array}$ & $\begin{array}{c}\text { Subjects with } \\
\text { systolic dys- } \\
\text { function (n=29) }\end{array}$ & $\begin{array}{c}\text { Subjects } \\
\text { with diastolic } \\
\text { dysfunction } \\
(\mathbf{n}=\mathbf{2 5})\end{array}$ & P \\
\hline ACE inhibitors or ARBs, n (\%) & $54(100 \%)$ & $29(100 \%)$ & $25(100 \%)$ & 0.72 \\
Beta-blockers, n (\%) & $42(77.7 \%)$ & $23(79.3 \%)$ & $19(76.0)$ & 0.68 \\
Ivabradine, n (\%) & $39(72.2 \%)$ & $21(72.4 \%)$ & $18(72.0 \%)$ & 0.70 \\
Mineralocorticoid receptor antagonists, n (\%) & $23(42.6 \%)$ & $12(41.3 \%)$ & $11(44.0 \%)$ & 0.84 \\
Loop diuretics, n (\%) & $54(100 \%)$ & $29(100 \%)$ & $25(100 \%)$ & 0.66 \\
Aspirin, n (\%) & $48(88.9 \%)$ & $25(86.2 \%)$ & $23(92.0 \%)$ & 0.042 \\
Other antiplatelets, n (\%) & $6(11.1 \%)$ & $4(13.8 \%)$ & $2(8.0 \%)$ & 0.046 \\
Statins, n (\%) & $54(100 \%)$ & $29(100 \%)$ & $25(100 \%)$ & 0.76 \\
\hline
\end{tabular}

Abbreviations: OR - odds ratio; OPG - osteoprotegerin; hs-CRP - high sensitive C-reactive protein

were elevated slightly-to-moderately. There were no significant differences between T2DM subjects with LVEF $\leq 45 \%$ and $46-55 \%$ regarding demographic, BMI, waist circumference, lipid abnormalities, blood pressure, heart rate, fasting blood glucose, and creatinine. However, hypertension, adherence to smoking, II and III NYHA class were found frequently in $\mathrm{T} 2 \mathrm{DM}$ patients with $\mathrm{LVEF}=46-55 \%$ when compared with those who had LVEF $\leq 45 \%$. Subjects with LVEF $\leq 45 \%$ demonstrated higher HOMA-IR, insulin, hs-CRP, NT-proBNP, osteoprotegerin, and adiponectin levels when compared with patients with $L V E F=46-55 \%$.

\section{RESULTS OF ECHOCARDIOGRAPHIC EXAMINATION}

The basic echocardiographic performances in CHF patients are presented in Table 2. We found lower longitudinal global strain and strain rate in T2DM patients with $\mathrm{LVEF} \leq 45 \%$ when compared with those who had $\mathrm{LVEF}=46-55 \%$ ( $\mathrm{P}=0.001$ for all cases $)$.

\section{TREATMENT SCHEME AMONG ENROLLED PATIENTS}

The concomitant treatment of CHF patients is presented in Table 3. All patients were treated with ACE inhibitors and angiotensin-II receptor blockers. There were no significant differences between both cohort patients in mineralocorticoid antagonist, beta-blocker, ivabradine, loop diuretic, and statin use. Aspirin was given frequently in subjects with LVEF $=46-55 \%(\mathrm{P}=0.042)$, in opposite, other antiplatelets were added frequently to the concomitant drugs in subjects with LVEF $\leq 45 \%(\mathrm{P}=0.046)$.
UNIVARIATE AND MULTIVARIATE LOGISTIC REGRESSION ANALYSIS

Using univariate logistic regression we found that global longitudinal strain and strain rate were closely associated with NT-proBNP $(\mathrm{r}=0.502 ; \mathrm{P}=0.001$ and $\mathrm{r}=0.414 ; \mathrm{P}=0.003$, respectively), NYHA class $(\mathrm{r}=0.405 ; \mathrm{P}=0.001$ and $\mathrm{r}=0.405 ; \mathrm{P}=0.001$, respectively), osteoprotegerin $(\mathrm{r}=0.426 ; \mathrm{P}=0.001$ and $\mathrm{r}=0.402$; $\mathrm{P}=0.006$, respectively), hs-CRP $(\mathrm{r}=0.412 ; \mathrm{P}=0.002$ and $\mathrm{r}=0.406 ; \mathrm{P}=0.001$, respectively), HOMA-IR $(\mathrm{r}=-0.353 ; \mathrm{P}=0.009$ and $\mathrm{r}=-0.348 ; \mathrm{P}=0.001$, respectively), LVEF ( $\mathrm{r}=0.24 ; \mathrm{P}=0.001$ and $\mathrm{r}=0.26$; $\mathrm{P}=0.001$, respectively), LDL cholesterol $(\mathrm{r}=0.204$; $\mathrm{P}=0.001$ and $\mathrm{r}=0.206 ; \mathrm{P}=0.001$, respectively), and age of the patients $(\mathrm{r}=0.202 ; \mathrm{P}=0.001$ and $\mathrm{r}=0.204$; $\mathrm{P}=0.001$, respectively). Therefore, we found close association between osteoprotegerin and NT-proBNP $(\mathrm{r}=0.436 ; \mathrm{P}=0.001)$, adiponectin $(\mathrm{r}=-0.443 ; \mathrm{P}=0.001)$, $\mathrm{BMI}(\mathrm{r}=0.422 ; \mathrm{P}=0.003)$, and NYHA class $(\mathrm{r}=0.402$; $\mathrm{P}=0.001)$.

Multivariate logistic regression analysis showed that NT-proBNP $(\mathrm{r}=0.432 ; \mathrm{P}=0.001$ and $\mathrm{r}=0.402$; $\mathrm{P}=0.001$, respectively), osteoprotegerin ( $\mathrm{r}=0.422$; $\mathrm{P}=0.001$ and $\mathrm{r}=0.401 ; \mathrm{P}=0.001$ respectively), hsCRP ( $\mathrm{r}=0.408 ; \mathrm{P}=0.001$ and $\mathrm{r}=0.404 ; \mathrm{P}=0.001$, respectively) were independently inversely associated with LV global longitudinal strain and strain rate in $\mathrm{CHF}$ patients.

Moreover, LV global longitudinal strain independently predicted a circulating levels of osteoprotegerin $(\mathrm{OR}=1.12 ; 95 \% \mathrm{CI}=1.06-1.19 ; \mathrm{P}=0.001)$ and NT-proBNP $(\mathrm{OR}=1.10 ; 95 \% \mathrm{CI}=1.04-1.17$; 
$\mathrm{P}=0.001$ ) (Table 4). The same variables were determined as predictors for declining LV global longitudinal strain rate. In multivariate models osteoprotegerin added to NT-proBNP better predicted myocardial contractility function $(\mathrm{OR}=1.18 ; 95 \%$ $\mathrm{CI}=1.11-1.23 ; \mathrm{P}=0.001)$ than osteoprotegerin $(\mathrm{OR}=1.12 ; 95 \% \mathrm{CI}=1.06-1.19 ; \mathrm{P}=0.001)$ alone and NT-proBNP alone $(\mathrm{OR}=1.10 ; 95 \% \mathrm{CI}=1.04-$ 1.17; $\mathrm{P}=0.001$ ).

\section{DISCUSSION}

The results of our study show that osteoprotegerin added to NT-proBNP predicts declining of global contractility function in T2DM patients with CHF. Surprisingly, hs-CRP, adiponectin, LVEF measured by echocardiography using the Simpson biplane model, and clinical criteria (NYHA class) were not defined as powerful independent tools for determination of worsening of global contractility function. Although global longitudinal strain is an excellent predictor of adverse LV remodeling and cardiac events in acute heart failure and decompensated CHF with preserved LVEF, T2DM patients with $\mathrm{CHF}$ are not considered optimal candidates for global longitudinal strain and strain rate measurements. ${ }^{25} \mathrm{In}$ fact, diabetic subjects even without overall obesity and lower LVEF may have significantly declining global longitudinal strain and strain rate. Therefore, a reasonable correlation between LVEF and global longitudinal strain was found in CHF subjects with declined LVEF $\leq 40 \% .{ }^{26} \mathrm{CHF}$ with preserved LVEF is frequently reported among T2DM patients. Although myocardial function assessment remains a challenging part of the echocardiographic examination, however, accuracy of the results closely depend on operator experience. Therefore, reproducibility of speckle tracking echocardiography remains a matter of controversy. ${ }^{27}$ Taken together, these facts appear to be argument for discovering a novel biological markers for risk stratification of the patients with CHF, which may increase utility of speckle tracking echocardiography.

Osteoprotegerin, hs-CRP, and NT-proBNP are defined as emerging biomarkers related to inflammatory activity and biomechanical stress that are associated with all-cause and cardiovascular mortality in CHF population. ${ }^{11,12}$ Kalaycıoğlu et al. ${ }^{12}$ reported that osteoprotegerin was found to be an independent predictor of impaired global longitudinal strain in hypertensive T2DM patients with subclinical left ventricular dysfunction. We have shown that osteoprotegerin added to NT-proBNP is able to predict worsening of global longitudinal strain and strain rate in both cohorts of T2DM patients with moderate-to-severe $\mathrm{CHF}$ including reduced LVEF and preserved LVEF. Recently osteoprotegerin was defined potentially as biomarker for cardiovascular risk in the metabolic syndrome and adipose tissue was identified as a potential source of osteoprotegerin synthesis. ${ }^{28}$ The results of our study confirm that osteoprotegerin added to NT-proBNP may improve prediction of declining of global contractility function in CHF patients with T2DM. Overall, a combination of both biomarkers included NT-proBNP and osteoprotegerin appears to be superior when compared with other models regarding lower LV global contractility function. Probably, biochemical stress that limits capacity of myocardial wall to deformation may be discussed as causal factor contributed in strain and strain rate. Indeed, osteoprotegerin is a member of tumor necrosis factor superfamily ${ }^{29}$ and it is expressed in vivo osteoblasts, endothelial cells, smooth muscle cells and cardiomyocytes ${ }^{30}$. Osteoprotegerin is a specific receptor for the ligand receptor activation of nuclear transcription factor kappa beta and TNF-alpha-dependent ligand inducing apoptosis. ${ }^{31}$ Osteoprotegerin is often seen as an indicator of inflammatory activation in opposite of NT-proBNP, which is reported as a powerful marker of biomechanical stress. ${ }^{32}$ Although causality factors that mediate secretion of both biomarkers are different, osteoprotegerin and NT-proBNP are able to emerge as result in stretch and tenderness of myocardial wall. Recent clinical studies have discussed such reaction in context of volume overload, worsening of CHF and acute heart failure presentation. ${ }^{33,34} \mathrm{We}$ report here that both biomarkers may be useful for prediction of decreased LV global contractility in T2DM patients with moderate-to-severe CHF, but adiponectin has not demonstrated similar ability. It is an unexpected result because of a close association of plasma osteoprotegerin and adiponectin was found in diabetic patient population. ${ }^{35}$ Therefore, it is well known that hs-CRP and adipocytokines are not able to improve integrative prediction for survival and admission rate in CHF patients. ${ }^{15}$ Thus, unexpectedly, osteoprotegerin and NT-proBNP were found as independent predictors of worsening of myocardial function in diabetic patients with $\mathrm{CHF}$, while recent clinical studies were not categorical regarding these biomarkers.

\section{StUdy Limitations}

This study has some limitations. The first limitation is 
the small sample size that may limit the significance of the present study and may increase the risk for a Type I error. The authors believe that a greater cohort of patients with more incidences detected is desirable to improve the credibility of the study. The second limitation is method of IR determination. We used the HOMA-IR equation for IR determination, while the euglycemic-hyperinsulinemic clamp technique is recommended optionally. It is needed to note that all CHF patients enrolled in the study were treated adequately and presented with stable clinical status. Antidiabetic drugs were given in several dose ranges that were adjusted individually and fixed by physician as optimal for patient. Probably, hypervolemic patients might be reported other results and we emphasize that state is the next study limitation. Moreover, this fact should be taken into consideration before extrapolation of our results on other patient populations including those who had LVEF $>55 \%$, non-ischemic CHF and probably dysmetabolic states. We did not divide T2DM patients with CHF regarding normal weight, overweight, and obesity because of small size was presented. Overall, this is a study limitation that was not able to check interplay between body mass and circulating level of biological markers in patients with strain and strain rate declining. However, the authors suggest that these restrictions might have no significant impact on the study data interpretation. To better understanding the role of inflammatory biomarkers in prediction of declining of LV global contractility function more investigations with increased sample size and prospective design are required.

\section{CONCLUSION}

We suggest that osteoprotegerin may be useful for making improvement of the NT-proBNP based model as predictor of decreased global contractility function in diabetic patients with CHF.

\section{CONFLICT OF INTERESTS}

Authors declare no conflict of interest.

\section{REFERENCES}

1. Dunlay SM, Roger VL. Understanding the epidemic of heart failure: past, present, and future. Curr Heart Fail Rep 2014;11:404-15.

2. Chamberlain AM, St Sauver JL, Gerber Y, et al. Multimorbidity in heart failure: a community perspective. Am J Med 2015;128:38-45.

3. Zafrir B, Goren Y, Salman N, et al. Comparison of body mass index and body surface area as outcome predictors in patients with systolic heart failure. Cardiol J 2015;22:375-81.

4. Khalid U, Ather S, Bavishi C, et al. Pre-Morbid Body Mass Index and Mortality After Incident Heart Failure: The ARIC Study. J Am Coll Cardiol 2014;64:2743-9.

5. Li ZJ, Du LF, Luo XH. Evaluation of ventricularvascular coupling in patients with type 2 diabetes mellitus using 2-dimensional speckle tracking imaging. J Huazhong Univ Sci Technolog Med Sci 2014;34:929-34.

6. Cheng S, McCabe EL, Larson MG, et al. Left ventricular mechanical function: clinical correlates, heritability, and association with parental heart failure. Eur J Heart Fail 2015;17:44-50.

7. Kalam K, Otahal P, Marwick TH. Prognostic implications of global LV dysfunction: a systematic review and meta-analysis of global longitudinal strain and ejection fraction. Heart 2014;100:1673-80.

8. Morris DA, Boldt LH, Eichstädt H, et al. Myocardial systolic and diastolic performance derived by 2-dimensional speckle tracking echocardiography in heart failure with normal left ventricular ejection fraction. Circ Heart Fail 2012;5:610-20.

9. Ersbøll M, Valeur N, Mogensen UM, et al. Prediction of all-cause mortality and heart failure admissions from global left ventricular longitudinal strain in patients with acute myocardial infarction and preserved left ventricular ejection fraction. J Am Coll Cardiol 2013;61:2365-73.

10. den Ruijter H, Pasterkamp G, Rutten FH, et al. Heart failure with preserved ejection fraction in women: the Dutch Queen of Hearts program. Neth Heart J 2015;23:89-93.

11. Aramburu-Bodas O, García-Casado B, SalamancaBautista P, et al. Relationship between osteoprotegerin and mortality in decompensated heart failure with preserved ejection fraction. J Cardiovasc Med (Hagerstown) 2015;16:438-43.

12. Kalaycı̆̆glu E, Gökdeniz T, Aykan A, et al. Osteoprotegerin is associated with subclinical left ventricular systolic dysfunction in diabetic hypertensive patients: a speckle tracking study. Can J Cardiol 2014;30:1529-34.

13.Don-Wauchope AC, McKelvie RS. Evidence based application of BNP/NT-proBNP testing in heart failure. Clin Biochem 2015;48:236-46.

14. Huynh K, Van Tassell B, Chow SL. Predicting therapeutic response in patients with heart failure: the story of C-reactive protein. Expert Rev Cardiovasc Ther 2015;13:153-61.

15. Kodziszewska K, Leszek P, Korewicki J, Piotrowski W. Old markers, new approach to assessment of risk in heart failure. Kardiol Pol 2015;73:387-95.

16. McMurray JJ, Adamopoulos S, Anker SD, et al. ESC 
guidelines for the diagnosis and treatment of acute and chronic heart failure 2012: The Task Force for the Diagnosis and Treatment of Acute and Chronic Heart Failure 2012 of the European Society of Cardiology. Developed in collaboration with the Heart Failure Association (HFA) of the ESC. Eur J Heart Fail 2012;14:803-69.

17. Executive summary. Standards of medical care in diabetes--2013. Diabetes Care 2013;36 Suppl 1:S4-10.

18. Schiller NB, Shah PM, Crawford M, et al. Recommendations for quantitation of the left ventricle by two-dimensional echocardiography. American Society of Echocardiography Committee on Standards, Subcommittee on Quantitation of Two-Dimensional Echocardiograms. J Am Soc Echocardiogr 1989;2:358-67.

19. Geyer H, Caracciolo G, Abe H, et al. Assessment of myocardial mechanics using speckle tracking echocardiography: fundamentals and clinical applications. J Am Soc Echocardiogr 2010;23:351-69.

20. Reisner SA, Lysyansky P, Agmon Y, et al. Global longitudinal strain: a novel index of left ventricular systolic function. J Am Soc Echocardiogr 2004;17:630-3.

21.Nagueh SF, Appleton CP, Gillebert TC, et al. Recommendations for the evaluation of left ventricular diastolic function by echocardiography. J Am Soc Echocardiogr 2009;22:107-33.

22. Levey AS, Stevens LA, Schmid CH, et al. A new equation to estimate glomerular filtration rate. Ann Intern Med 2009;150:604-12.

23. Matthews DR, Hosker JP, Rudenski AS, et al. Homeostasis model assessment: insulin resistance and beta-cell function from fasting plasma glucose and insulin concentrations in man. Diabetologia 1985;28:412-9.

24. Friedewald WT, Levy RI, Fredrickson DS. Estimation of the concentration of low-density lipoprotein cholesterol in plasma, without use of the preparative ultracentrifuge. Clin Chem 1972;18:499-502.

25. Wang Q, Gao Y, Tan K, et al. Subclinical impairment of left ventricular function in diabetic patients with or without obesity : A study based on three-dimensional speckle tracking echocardiography. Herz 2015;40 Suppl 3:260-8.

26. Benyounes N, Lang S, Soulat-Dufour L, et al. Can global longitudinal strain predict reduced left ventricular ejection fraction in daily echocardiographic practice? Arch Cardiovasc Dis 2015;108:50-6.

27. Fontana A, Zambon A, Cesana F, et al. Tissue Doppler, triplane echocardiography, and speckle tracking echocardiography: different ways of measuring longitudinal myocardial velocity and deformation parameters. A comparative clinical study. Echocardiography 2012;29:428-37.

28. Pérez de Ciriza C, Moreno M, Restituto P, et al. Circulating osteoprotegerin is increased in the metabolic syndrome and associates with subclinical atherosclerosis and coronary arterial calcification. Clin Biochem 2014;47:272-8.

29. Montagnana M, Lippi G, Danese E, et al. The role of osteoprotegerin in cardiovascular disease. Ann Med 2013;45:254-64.

30. Emery JG, McDonnell P, Burke MB, et al. Osteoprotegerin is a receptor for the cytotoxic ligand TRAIL. J Biol Chem 1998;273:14363-7.

31. Olesen P, Ledet T, Rasmussen LM. Arterial osteoprotegerin: increased amounts in diabetes and modifiable synthesis from vascular smooth muscle cells by insulin and TNF-alpha. Diabetologia 2005;48:561-8.

32. Andersen G, Knudsen EC, Aukrust P, et al. Elevated serum osteoprotegerin levels measured early after acute ST-elevation myocardial infarction predict final infarct size. Heart 2011;97:460-5.

33. Hofbauer LC, Schoppet M. Clinical implications of the osteoprotegerin/RANKL/RANK system for bone and vascular diseases. JAMA 2004;292:490-5.

34. Røysland R, Masson S, Omland T, et al. Prognostic value of osteoprotegerin in chronic heart failure: The GISSI-HF trial. Am Heart J 2010;160:286-93.

35.Chen WJ, Rijzewijk LJ, van der Meer RW, et al. Association of plasma osteoprotegerin and adiponectin with arterial function, cardiac function and metabolism in asymptomatic type 2 diabetic men. Cardiovasc Diabetol 2011;10:67. 


\title{
Глобальная лонгитудинальная деформация и степень деформации у пациентов с диабетом типа 2 и хронической сердечной недоста- точностью: связь с остеопротегерином
}

\author{
Петер Кружляк ${ }^{1}$, Александр Бережин ${ }^{2}$, Александр Кремцер ${ }^{3}$, Татьяна Самура \\ Роман Бенака 4 , Иоана Мозос 5 , Эмануель Эгом ${ }^{6}$, Луис Родриго7 \\ 1 Университет ветеринарной медицины и фармацевтики, Лаборатория структурной биологии и протеомики, Брно, Чеш- \\ ская Республика \\ 2 Кафедра внутренней медицины, Государственный медицинский университет, Запорожье, Украина \\ ${ }^{3}$ Кафедра клинической фармакологии, Государственный медицинский университет, Запорожье, Украина \\ ${ }^{4}$ Benimed Ltd \\ ${ }^{5}$ Кафедра функциональных наук, Университет медицины и фармацевтикия им. Виктора Бабеса, Тимишоара, Румыния \\ ${ }^{6}$ Дублинский университет, Тринити Колледж, Кафедра клинической медицины, отдел "Образование", Дублин, Ирландия \\ 7 Университет Овьедо, Центральная университетская больница Астурия, Овьедо, Испания
}

\section{Для корреспонденции: Петер Кружляк, Университет ветеринарной медицины и фармацевтики, Лаборатория структурной биологии и протеомики, Palackeho tr 1946/1 \\ Брно, 612 42, Чешская Республика \\ E-mail: peter.kruzliak@savba.sk Tel.: +420543181111; mob: $+420543181111$}

Дата получения: 26.05.2016 г. Дата приемки: 31.05.2016 г. Дата онлайн публикации: 25.07.2016 г.

Дата публикации: 30.09.2016 г.

Ключевые слова: хроническая сердечная недостаточность; глобальная продольная деформация и степень деформации, мозговой натрийуретический пептид

Цитаты: Кружляк П., Кремцер А., Самура Т., Бенака Р., Мозос И., Эдом Э., Родриго Л. Глобальная продольная деформация и скорость деформации у пациентов с диабетом типа 2 и хронической сердечной недостаточностью: связь с остеопротегерином.

Журнал "Folia Medica" 2016;58(3);164-173, doi: 10.1515/folmed-2016-0021
Обоснование: Биомеханическое напряжение и воспалительные биомаркеры связаны с глобальной контрактильной дисфункцией, но включение этих биомаркеров в модель риска, разработанную на базе клинических данных, не улучшает ее предиктивный показатель при хронической сердечной недостаточности (XCH).

Цели: Целью настоящего исследования является оценка возможности прогнозирования ухудшения глобальной контрактильной функции левой камеры у пациентов-диабетиков с ишемической ХСН с помощью биомаркеров.

Пациенты и методы: В рамках исследования ретроспективно было выбрано 54 пациента-диабетика, страдающих систолической или диастолической ишемической ХCH, которая была определена как фракция выброса левого желудочка (ФВЛЖ) $\leq 45 \%$ или 46-55\% и, соответственно, измерена с помощью количественной эхокардиографии и других конвенциональных критериев в соответствии с актуальными клиническими указаниями. Была проведена двухмерная трансторакальная эхокардиография и допплеровское исследование тканей конвенциональным методом. Радиальная, продольная и циркумферентная деформация и ее показатели были получены с помощью визуального анализа Спекл-трекинг как короткой, так и длинной оси левого желудочка. Сывороточный уровень адипонектина, NT-рrо мозгового натрийуретического пептида (BNP), остеопротегерина и высокочувствительного C-реактивного протеина (hs-CRP) был определен на исходном уровне с помощью ELISA.

Результат: Была выявлена меньшая лонгитудинальная деформация (стрейн) и степень деформации у пациентов-диабетиков с ФВЛЖ <45\% по сравнению с теми, у которых отсутствует ( $\mathrm{P}=0.001$ во всех случаях). Мультиноминальная логистическая регрессия показала, что NT-proBNP ( $r=0.432 ; \mathrm{P}=0.001$ и $\mathrm{r}=0.402$; $\mathrm{P}=0.001$ соответственно), остеопротегерин ( $\mathrm{r}=0.422 ; \mathrm{P}=0.001$ и $\mathrm{r}=0.401 ; \mathrm{P}=0.001$ соответственно), hs-CRP ( $r=0.408 ; \mathrm{P}=0.001$ и $r=0.404$; $\mathrm{P}=0.001$ соответственно) связаны самостоятельно и обратно пропорционально с глобальной лонгитудинальной деформацией у пациентов с ХCH.

Заключение: Предполагаем, что остеопротегерин может быть полезен для улучшения NT-proBNP модели, как предиктивный показатель пониженной глобальной систолической функции у пациентов-диабетиков с XCH. 